\title{
GROWTH OF A POPULATION OF Cabralea canjerana IN A NATURAL REGENERATION STAGE IN THE SECONDARY FOREST WITH USE OF THE LIBERATION
}

\author{
Anna Paula Lora Zimmermann ${ }^{*}$, Frederico Dimas Fleig² \\ $1 *$ Federal University of Santa Maria, Graduate Program in Forest Engineering, Santa Maria, RS, Brazil. E-mail: zimmermann- \\ a@hotmail.com (*AUTHOR FOR CORRESPONDENCE: zimmermann-a@ hotmail.com) \\ 1 * Federal University of Santa Maria, Post-graduate Program in Forest Engineering, Santa Maria, RS, Brazil. E-mail: \\ dimasfleig@uol.com.br
}

Received for publication: 26/06/2018 - Accepted for publication: 25/09/2018

\begin{abstract}
Resumo
Crescimento de uma população de Cabralea canjerana em estágio de regeneração natural em floresta secundária com $o$ uso da liberação. Este trabalho objetivou verificar a influência da técnica de liberação no crescimento de uma população jovem de Cabralea canjerana e baseado nisto determinar a melhor dimensão para as plantas serem liberadas e verificar as diferenças no crescimento entre plantas emergentes e dominadas. A liberação consistiu no corte raso de todas as espécies diferentes à espécie de interesse, sendo liberadas 90 árvores da espécie e 73 mantidas em competição (testemunha). As variáveis altura total e diâmetro a $10 \mathrm{~cm}$ do solo foram mensuradas antes e anualmente por quatro anos após a liberação. Ao final do experimento foram mensuradas as variáveis diâmetro de copa, comprimento de copa e altura de inserção dos galhos, as árvores foram classificadas conforme sua posição sociológica (emergentes ou dominadas). Os dados foram submetidos a testes de médias no pacote estatístico SISVAR. Plantas liberadas apresentaram incremento superior tanto em altura quanto diâmetro às árvores que não foram liberadas. Contudo, o ganho de incremento em diâmetro e altura foi superior quando realizado em plantas com até $100 \mathrm{~cm}$ de altura, principalmente se as plantas forem capazes de se tornarem emergentes. Árvores emergentes não liberadas apresentaram maior altura de inserção de galhos no fuste, o que na prática demonstra maior proporção de fuste livre de nós. Assim, conclui-se que a liberação estimula o crescimento de árvores jovens de C. canjerana.

Palavras-chave: Sucessão secundária; desbastes de liberação; cortes seletivos; incremento; desrama.
\end{abstract}

\begin{abstract}
This work aimed to verify the influence of the liberation technique on the growth of a young population of Cabralea canjerana, based on this to determine the best size for the plants to be liberated and to verify the differences in growth between emergent and dominate plants. The liberation consisted of the clear cutting of all species different from the species of interest, with 90 trees from the species being liberated and 73 being kept in competition (control). The variables total height and diameter at $10 \mathrm{~cm}$ from the soil were previously and annually, for four years after the liberation, measured. At the end of the experiment the crown diameter, crown length and branch insertion height were measured and the trees were classified according the treatment and sociological position (emergent or dominated). The data were submitted to means tests in the statistical package SISVAR. Liberated plants showed a higher increase in diameter or height than not liberated trees. However, the increase gain in diameter and height is higher when realized in plants up to $100 \mathrm{~cm}$ high, especially if the plants are able to become emergent. Not liberated emergent trees showed higher branch insertion height in the stem, which in practice shows a higher proportion of stem free from nodes. Thus, it is concluded that the liberation stimulates the growth of young trees of $C$. canjerana.

Keywords: Secondary succession; liberation thinning; selection cutting; increment; pruning.
\end{abstract}

\section{INTRODUCTION}

Forests present mechanisms by which they are able to recover after natural or anthropogenic disturbances. Secondary succession is the process in which degraded or disturbed primary forests can return to the same or similar conditions by growing native or exotic species (ORTEGA-PIECK et al., 2011). This process begins after the opening of a clearing, where conditions are created for the establishment of pioneer species that create microclimatic conditions for secondary species, increasing species diversity in the locality (HUGHES et al., 2012).

However, undesirable species and vines also have the capacity to reestablish themselves in degraded areas, and can often prevent the natural recovery process of the forest due to its excessive growth (ESQUIVEL et al., 2008). These species hinder the growth and establishment of native species due to competition for water, nutrients and mainly light (ORTEGA-PIECK et al., 2011).

FLORESTA, Curitiba, PR, v. 49, n. 3, p. 553 - 560, jul/set 2019.

Zimmermann, A. P. L. et.al.

ISSN eletrônico 1982-4688

DOI: $10.5380 /$ rf.v49 i3.60142 
Since luminosity has a determining influence on tree growth and species regeneration rate, leading the process of succession and shaping the secondary stratum, the main challenge for the management of tropical forests is to maintain an opening in the canopy capable of favoring the growth of desirable species of the pioneer and secondary group without allowing invasive species to enter (SOUZA et al., 2015).

Light manipulation in forests can be done through a silvicultural technique called liberation. The liberation is the opening of the canopy through the realization of undesirable tree cuttings to favor the development of promising trees. The technique is based on the assumption that the growth rate of trees is proportional to the degree of exposure of the canopy to light and inversely proportional to competition (DAWKINS, 1955).

Studies carried out by Peña-Claros et al. (2008) and Villegas et al. (2009) in tropical forests, have shown that the application of the liberation significantly increased the rate of growth of the species. Souza et al. (2015) also verified an expressive gain in increment for species that received slabs of liberation and cuts of canopy.

Even though growth rates can be accelerated by silvicultural treatments, according to Vatraz et al. (2012), there are still gaps to be elucidated in the management of forests of most species of commercial interest, mainly in relation to growth pattern responses to the accomplishment of these techniques.

Cabralea canjerana is one of the most important species of the Decidual Seasonal Forest in Rio Grande do Sul. The species was extensively exploited in the past, both for its use, because it presents high quality wood and durability, and by deforestation, made to clear areas for crops. Because of the exploitation, the species is now considered vulnerable to extinction in the list of endangered species. However, due to the abandonment of agricultural areas, it is currently common to find young populations of canjerana under high density in secondary forest fragments, mainly under the canopy, since the species belongs to the late secondary group.

Although secondary species, such as Cabralea canjerana (Vell.) Mart., Have the ability to germinate and survive in the shade for years, they tend to grow vertically in their young phase in the attempt to reach the canopy and only when they reach it, they invest in the growth of the canopies (ALMEIDA, 2016). For this reason, species of this group require light stimuli throughout their life cycle. However, this is a process that can take years to happen naturally, often requiring human interventions to continue the process.

Thus, this work aims to analyze the influence of the liberation on the periodic increment in diameter and height and in the form of young trees of Cabralea canjerana and verify which dimension regarding height the trees must have to respond better to the application of the treatment.

\section{MATERIALS AND METHODS}

The study was carried out in the municipality of Silveira Martins, Central region of the State of Rio Grande do Sul. The climate according to the classification of Köppen is of type Cfa, subtropical humid, with average annual temperature of $18^{\circ} \mathrm{C}$ and average annual precipitation of $1700 \mathrm{~mm}$ (ALVARES et al., 2013). Soils, according to Embrapa (2013), are typical Neosols, characterized by low depth and spots with visible stonyness.

The sample area is a fragment of secondary Seasonal Forest, where in the past there was cattle grazing. The area was isolated about 25 years ago and natural regeneration formed a thin canopy approximately 6 meters high. In it, seventy-seven continuous permanent plots $\left(5 \times 5 \mathrm{~m}\right.$ each) were installed, totaling $1925 \mathrm{~m}^{2}$ of sampled area.

All plants of $C$. canjerana with height equal or greater than $30 \mathrm{~cm}$ were counted and numbered. The following variables were measured: diameter at $10 \mathrm{~cm}$ of the ground (d), because it deals with a population in period of natural regeneration; total height (h), height of insertion of the canopy (hic), length of pantry (cc) and diameter of pantry (dc). Caliper, tapeline and Vertex hypsometer were equipments that were used when necessary.

The liberation was done through shallow cutting, eliminating all trees of species different than the species of interest, remaining in these plots only $C$. canjerana. In order to balance to the maximum the number of plants of the same size in the two treatments and being intended to assort the freed parcels, in order to minimize the shadowing for the neighboring trees, it was defined that the liberation would be carried through in thirty of the seventy seven parcels of the area (Figure 1).

Thus, 90 plants were released and 73 were kept under the original vegetation, being considered the control treatment. In the first years, whenever it was necessary, maintenance was performed in this area in order to avoid shadowing of the released plants. 


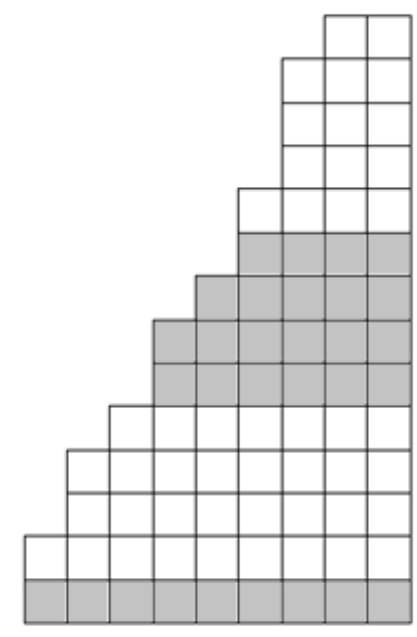

Figura 1. Esquema de instalação das parcelas do experimento, com destaque para as parcelas onde foi realizada a liberação de plantas jovens de Cabralea canjerana.

Figure 1. Scheme the installation of the plots the experiment, highlighting for the plots where the young plants of Cabralea canjerana were liberated.

Since it was observed great heterogeneity of luminosity in the plants located in the plots without liberation, the light incidence with lux meter was measured. The measurement was performed at the central point of the crown of each plant, on a clear day, between 11:00 and 13:00 hours. Considering that in open area the trees were receiving $100 \%$ of luminosity, the luminosity incident on the trees was determined through the Relative Luminosity Index (RLI):

$$
R L I=(\text { forest light }) /(\text { light open area }) \cdot 100
$$

Where: RLI: relative brightness index; forest light: value obtained in the lux meter in the parcels without liberation; light open area: value obtained in the lux meter in the parcels where the liberation occurred.

As the seeds of $C$. canjerana are dispersed by birds, their spatial distribution is of grouped form. Therefore, although the liberation has eliminated the competition of other species on C. canjerana, in the area of treatment application, the competition started to be only between plants of the species. In order to quantify the competition of the canjerana on the liberated plants and those of other species and on the not liberated plants, the total basal area of the plot was used, calculated by the sum of the basal areas of all the plants of the plot.

The plants were measured right after liberation and annually, for four years, to determine the periodic increment in diameter and height. In the last evaluation, the crown diameter, canopy length and height of insertion of the branches were also measured. On this occasion, the plants were also classified according to their sociological position in the forest (non-liberated area) or in the groups formed by the species itself (liberated area). Emerging species were those that were able to reach the canopy of the unleashed area (NLE) or excelled in the groups of the species (LE) and dominated the others that remained shaded by other species (NLD) or only by canjerana (LD). The incremental rates were also analyzed according to the initial height of the plants at the time of liberation, and three size classes were analyzed: $30 \mathrm{~cm}<\mathrm{h}<100 \mathrm{~cm} ; 100 \mathrm{~cm}<\mathrm{h}<200 \mathrm{~cm} ; \mathrm{h}>200 \mathrm{~cm}$.

The Pearson correlation analysis was performed between the periodic increments in diameter and height and the dendrometric, morphometric, competition index and relative brightness index to verify the degree of association between the variables.

The Shapiro-Wilk tests were performed to verify the data normality and Bartlett tests for homogeneity of variances. When the data did not meet the assumptions, they were transformed by the Box-Cox function. The values of the increments were compared using the mean $\mathrm{T}$ tests to verify the difference between liberated and nonliberated trees and Tukey's test, in order to verify the difference between the four sociological groups (LE, NLE, LD, NLD). Both tests were performed in the SISVAR statistical package at $5 \%$ error probability.

\section{RESULTS}

In general, the periodic increases in diameter and height of the non-liberated trees presented higher correlation values than the liberated trees (Table 1). In general, the increments correlated better with the initial and 
final dimensions of the trees, as well as the canopy variables. The relative brightness index and the initial basal total area of the plot had low correlation with the periodic increments in diameter and height and could not be used to explain the influence of light and competition on the growth of the trees analyzed.

Liberated trees presented greater periodic increment in diameter (PID) and height (PIH) than not liberated trees, but with statistic difference only for the PID, according to test $\mathrm{T}$, at a 5\% error probability (Table 1). When analyzing the rates of periodic increment in diameter and height, according to the height dimension that the plants had when they were liberated, it is observed that the liberation had different effects on the plants of $C$. canjerana. As it can be seen in Figure 2, where the continuous line represents the total value of the periodic increments in diameter and height of the non-liberated trees; it is observed that the release provided a gain in diameter increase in the liberated trees, regardless of the height dimension that they had when liberated. However, the liberation in trees of up to 1 meter in height propitiated a gain of increment in diameter of $56 \%$ in relation to trees of the same size that were not liberated. In the other height classes, the liberation promoted a gain of increment in diameter of around $20 \%$.

On the other hand, the effect of the liberation on the periodic increment in height was observed only in plants that were up to 1 meter in height when liberated, which presented $61 \%$ more of periodic increment in height (PIH) in relation to non-liberated same size trees. Trees that had initial height above this limit did not respond to the liberation, presenting about $10 \%$ less of PIH than trees that were kept under natural competition.

Tabela 1. Correlação de Pearson entre os incrementos periódicos em diâmetro e altura de árvores jovens de $C$. canjerana liberadas e não liberadas e suas variáveis dendrométricas, morfométricas e índices de competição.

Table 1. Pearson correlation between the periodic increments in diameter and height of young trees of C. canjerana liberated and not liberated and their dendrometric, morphometric and competition indexes.

\begin{tabular}{|c|c|c|c|c|c|c|}
\hline \multirow{2}{*}{ Treatment } & \multirow{2}{*}{ Variable } & \multirow{2}{*}{ Average } & \multicolumn{2}{|c|}{ PID } & \multicolumn{2}{|c|}{ PIH } \\
\hline & & & $\mathbf{p} *$ & Prob. & $\mathbf{p} *$ & Prob. \\
\hline \multirow{10}{*}{ Non-liberated } & di & $1.7 \mathrm{a}$ & 0.600 & 0.002 & 0.593 & 0.000 \\
\hline & hi & $1.1 \mathrm{a}$ & 0.525 & 0.000 & 0.521 & 0.000 \\
\hline & df & $5.1 \mathrm{a}$ & 0.929 & 0.000 & 0.816 & 0.000 \\
\hline & hf & $4.0 \mathrm{a}$ & 0.816 & 0.000 & 0.954 & 0.000 \\
\hline & $\mathrm{dc}$ & $184.2 \mathrm{a}$ & 0.745 & 0.000 & 0.591 & 0.000 \\
\hline & $\mathrm{cc}$ & $121.2 \mathrm{a}$ & 0.690 & 0.000 & 0.796 & 0.000 \\
\hline & RLI & $32.8 \mathrm{a}$ & 0.335 & 0.002 & 0.280 & 0.010 \\
\hline & $\mathrm{Gi}$ & $0.0132 \mathrm{a}$ & 0.171 & 0.122 & 0.112 & 0.315 \\
\hline & PID & $3,4 \mathrm{a}$ & 1.000 & 1.000 & 0.832 & 0.000 \\
\hline & $\mathrm{PIH}$ & $2.9 \mathrm{a}$ & 0.832 & 0.000 & 1.000 & 1.000 \\
\hline \multirow{10}{*}{ Liberated } & di & $2.0 \mathrm{a}$ & 0.257 & 0.022 & 0.292 & 0.009 \\
\hline & hi & $1.3 \mathrm{a}$ & 0.253 & 0.025 & 0.223 & 0.048 \\
\hline & $\mathrm{df}$ & $6.8 \mathrm{~b}$ & 0.923 & 0.000 & 0.715 & 0.000 \\
\hline & $\mathrm{hf}$ & $4.7 \mathrm{a}$ & 0.719 & 0.000 & 0.945 & 0.000 \\
\hline & $\mathrm{dc}$ & $205.0 \mathrm{a}$ & 0.564 & 0.000 & 0.452 & 0.000 \\
\hline & $\mathrm{cc}$ & $135.4 \mathrm{a}$ & 0.675 & 0.000 & 0.786 & 0.000 \\
\hline & RLI & $89.1 \mathrm{~b}$ & 0.288 & 0.002 & 0.247 & 0.019 \\
\hline & $\mathrm{Gi}$ & $0.0101 b$ & 0.146 & 0.199 & 0.085 & 0.458 \\
\hline & PID & $4.8 \mathrm{~b}$ & 1.000 & 1.000 & 0.729 & 0.000 \\
\hline & $\mathrm{PIH}$ & $3.4 \mathrm{a}$ & 0.729 & 0.000 & 1.000 & 1.000 \\
\hline
\end{tabular}

Where: PID: periodic increment in diameter $(\mathrm{cm})$; PIH: periodic increase in height $(\mathrm{m})$; id: initial diameter (cm); ih: initial height (m); fd: final diameter $(\mathrm{cm})$; fh: final height $(\mathrm{m})$; cd: crown diameter $(\mathrm{cm})$; cl: crown length $(\mathrm{cm})$; RLI: relative lightness index; Gi: total initial basal area of the $\operatorname{plot}\left(\mathrm{m}^{2}\right) ; \mathrm{p}$ *: Pearson's correlation coefficient; Prob: Probability. Averages followed by the same letter are not differentiated by the T test. 


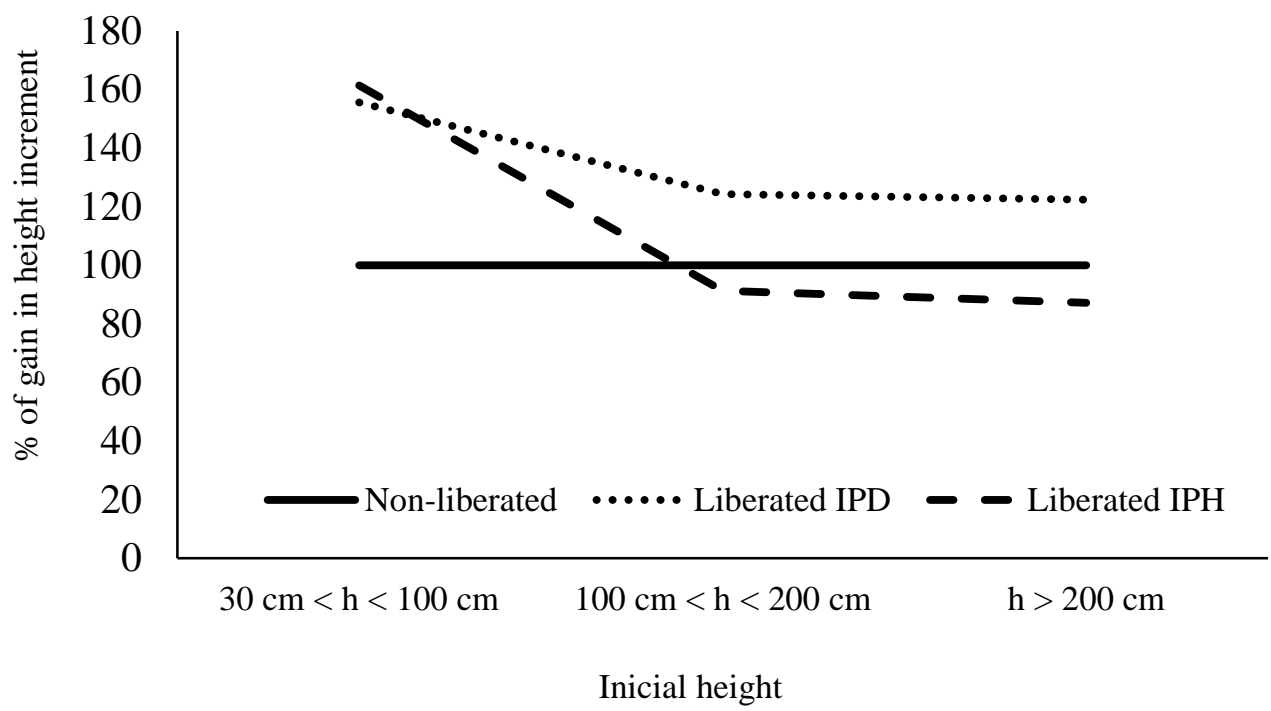

Figura 2. Ganho percentual de incremento periódico em diâmetro (IPD) e altura (IPH) de árvores de Cabralea canjerana de acordo com a dimensão de altura que possuíam ao serem liberadas em relação às árvores de mesmo tamanho sem liberação. A linha contínua representa o valor total dos incrementos periódicos em diâmetro e altura das árvores não liberadas. As linhas pontilhada e tracejada representam o valor percentual do incremento periódico em diâmetro e altura, respectivamente, das plantas liberadas em relação ao valor total dos incrementos em diâmetro e altura das plantas não liberadas.

Figure 2. Percentage gain of periodic increment in diameter (IPD) and height (IPH) of Cabralea canjerana according to the height dimension they had when liberated in relation to trees of the same size without liberation. The continuous line represents the total value of the periodic increments in diameter and height of the trees not liberated. The dotted and dashed lines represents the value of the periodic increment in diameter and height, respectively, of the plants liberated in relation to the total value of the increments in diameter and height of the plants not liberated.

Of the ninety plants of $C$. canjerana that were liberated, twenty-eight have become emergents. Of seventy tree trees that did not received liberation treatment, thirtheen of them have become emergents and were able to reach the canopy of the vegetation through its own strategies os allocation of resources (Tabela 2).

Emergent liberated and non-liberated trees presented increment rates in similar heights and with no statistical differences, being the same observed to the group of dominateds. On the other side, the liberation propitiated a bigger increment in diameter for the emergent trees (LE), with statistical differences from the other groups. Liberated dominated plants (LD) displayed a increment rates with no statistical difference of plants in the same sociological position without liberation (NLD)

Non-liberated emergent trees (NLE) presented a higher proportion of clean stem because they presented higher height of insertion of the first branch. This dimension is related to crown length, since the trees in this group have shorter crowns when compared to liberated emergent trees (LE). The release stimulated the elongation and the expansion of the canopy of the emergent trees, because these have larger dimensions of length and crown diameter. Regardless of the treatment to which they were submitted, dominated trees have a similar crown shape, with a smaller diameter and length than the emergent ones.

Tabela 2. Incremento periódico em altura total e diâmetro e dimensões finais de árvores jovens de $C$. canjerana liberadas e não liberadas em floresta secundária, RS, Brasil.

Table 2. Periodic increase in total height and diameter and final dimensions of young trees of the C. canjerana liberated and not liberated in secondary forest, RS, Brazil.

\begin{tabular}{ccccccccc}
\hline \multirow{2}{*}{ Group } & \multicolumn{3}{c}{ Periodic increment } & \multicolumn{5}{c}{ Final dimension } \\
\cline { 2 - 9 } & $\mathrm{N}$ & $\mathrm{ih}$ & $\mathrm{id}$ & $\mathrm{fh}$ & $\mathrm{fd}$ & $\mathrm{hig}$ & $\mathrm{cc}$ & $\mathrm{cd}$ \\
\hline LE & 28 & $5.1 \mathrm{a}$ & $6.8 \mathrm{a}$ & $6.9 \mathrm{a}$ & $9.6 \mathrm{a}$ & $4.7 \mathrm{a}$ & $218.0 \mathrm{a}$ & $239.0 \mathrm{a}$ \\
\hline NLE & 13 & $5.1 \mathrm{a}$ & $5.2 \mathrm{~b}$ & $7.2 \mathrm{a}$ & $7.4 \mathrm{~b}$ & $5.4 \mathrm{a}$ & $186.0 \mathrm{~b}$ & $194.0 \mathrm{ab}$ \\
\hline LD & 62 & $2.7 \mathrm{~b}$ & $4.0 \mathrm{c}$ & $2.7 \mathrm{~b}$ & $5.6 \mathrm{c}$ & $2.7 \mathrm{~b}$ & $106.0 \mathrm{c}$ & $189.0 \mathrm{~b}$ \\
\hline NLD & 60 & $2.4 \mathrm{~b}$ & $3.0 \mathrm{c}$ & $3.4 \mathrm{~b}$ & $4.5 \mathrm{c}$ & $2.3 \mathrm{~b}$ & $98.0 \mathrm{c}$ & $181.0 \mathrm{~b}$ \\
\hline
\end{tabular}

Where: LE: liberated emergents; NLE: non-liberated emergents; LD: liberated dominated; NLD: non-liberated dominated; N: number of trees; hi: total height increment $(\mathrm{m})$; di: diameter increment $(\mathrm{cm})$; hf: final total height $(\mathrm{m})$; df: final diameter $(\mathrm{cm})$; hig: height of insertion of the 
branches $(\mathrm{m})$; cc: crown length $(\mathrm{cm})$; dc: crown diameter $(\mathrm{cm})$; averages followed by the same letter do not differ statistically by the Tukey test at $5 \%$ of error probability.

The behavior of annual incremental rates in diameter was similar for LE, NLD and NLE trees, which increased in diameter in the first two years after release (Figure 3a). Dominated emerged and unresolved released trees showed the highest and lowest absolute rates of annual increment in diameter, respectively.

A slight drop in the growth of these groups could be seen between the years 2015 and 2016, but with a resumption of growth in the following year. On the other hand, LD trees showed a constant decrease in the rate of increment in diameter over the analyzed period.

The rate of increment in height of the species presented similar behavior throughout the analyzed period, for all groups of plants (Figure 3b). The annual periodic increment in height remained increasing until the third year after the release in the area. In the last year, all groups showed a decrease in the rate of increase, being equal to LD, NLD and NLE trees.

Non-liberated trees that reached the canopy (NLE) presented periodic incremental rates in height superior than the trees that were liberated and became dominant in the groups formed only by the species $C$. canjerana.
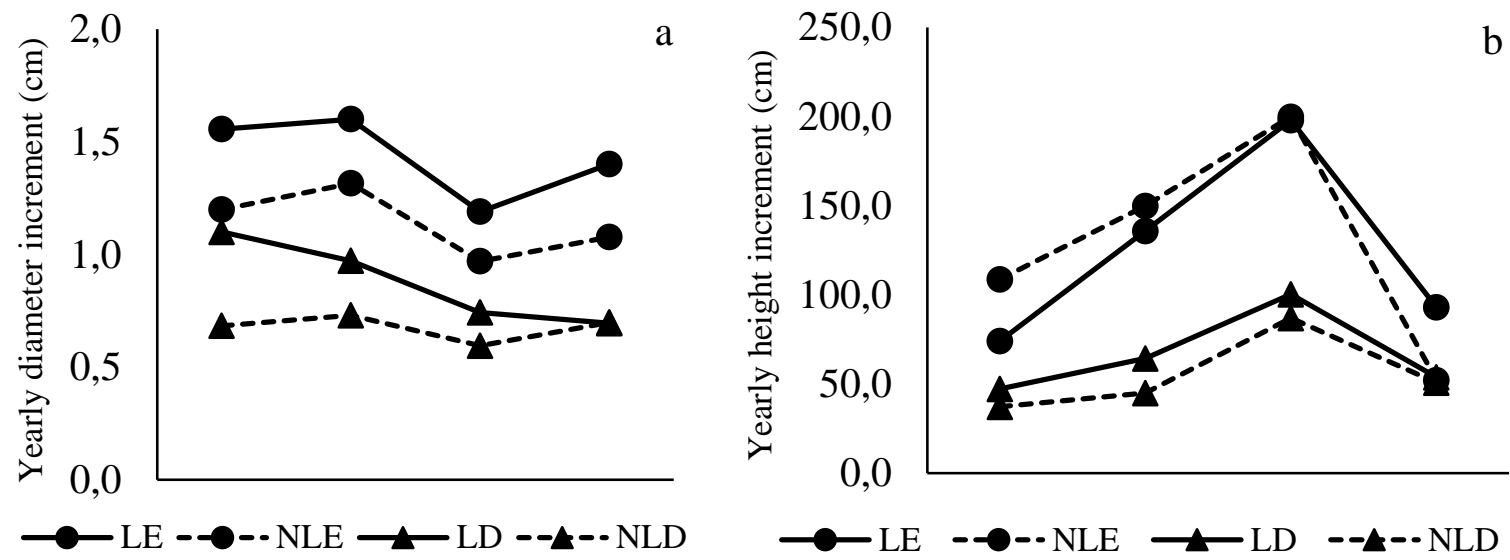

Where: LE: liberated emergents; NLE: non-liberated emergents; LD: liberated dominated; NLD: non-liberated dominated

Figura 3. Comportamento da taxa de incremento anual em diâmetro (a) e altura (b) de plantas jovens de $C$. canjerana dominadas e emergentes, liberadas e não liberadas.

Figure 3. Behavior of annual growth rate in diameter (a) and height (b) of young plants of $C$. canjerana dominated and emerging, liberated and not liberated.

\section{DISCUSSION}

The largest increment in diameter in liberated trees is expected, since this variable is strongly dependent on competition, presenting a relation inversely proportional to this variable (PRETZSCH, 2009). Even if released trees showed a greater periodic increment in height, the smallest difference between these values without statistical difference may be related to the fact that the tallest trees had already received a certain amount of light in their canopy. Thus, when liberated, they were not exposed to such different conditions to which they were already acclimatized.

The gain of diameter increment in trees released regardless of the height dimension that the plant had when released shows that the species is able to respond positively to the treatment, proving that, this technique can be indicated to be carried out in the initial and young phase of $C$. canjerana when the interest is to promote growth in diameter. However, the increment gain in height, observed only in plants with initial dimensions up to $100 \mathrm{~cm}$ in height, demonstrates that the liberation was not enough to stimulate the growth in height of the trees. The maintenance of competition in the young phase of the species stimulates growth in height (LINKEVICIUS et al., 2014). Because it is a late secondary species, the competition encouraged the increase in height of the trees not released from canjerana, because these invested in vertical growth in order to seek luminosity for their crowns.

The fact that only $31.1 \%$ of the liberated plants became emergent serves to show that the application of the liberation technique based only on the suppression of competing species different than the specific species was not enough to overcome the competition and promote the growth in height of $C$ Canjerana. Although there was a decrease in the competition for the cut of the other species in the area, the intraspecific competition remained active on the plants. Intraspecific competition, or self-competition, has more severe effects under plants, because 
the more genetically similar, the more similar their environmental requirements will be (ZANINE; SANTOS, 2004).

Even when released, but under self-competition, only the plants that were able to express their ability to use the resources presented enough increment to reach the canopy in the groups formed by the species. According to Scarpinati et al. (2009), differences in resource reuse capacity results in different rates of increment in height, and are responsible for the formation of forest strata. Thus, plants that did not allocate sufficient resources were overcome by self-competition and eventually dominated, remaining below the emergent canopy.

The similarity in the rate of periodic increment in height in trees of the same sociological position infers that the liberation did not stimulate the growth in height of the trees that received this treatment. According to Prodan et al. (1997), the growth in height of a species is determined by the quality of the site and the rate of increment of this variable is a response to the environmental conditions of the place, not being influenced by the competition.

Although the liberation did not promote the desired effect on the height growth of young trees of $C$. canjerana, liberated trees had a higher rate of increase in diameter, demonstrating the efficiency of the application of this technique to obtain a higher volume of wood. Growth in diameter is adversely affected by competition (STERBA, 2006). The reduction of the increment in diameter of the trees of $C$. canjerana under competition can be explained by the necessity of these trees to allocate resources for the growth in height. According to Schneider and Schneider (2008), the growth in height causes the trees to sacrifice growth in diameter prioritizing longitudinal growth.

In addition to the dendrometric variables, the reduction of competition also influenced the morphometry of the trees of $C$. canjerana, especially of the emergent ones, which presented wider and longer crowns. According to Sterba (2006), lateral competition hinders the vertical and horizontal expansion of the canopy, causing trees under competition to have smaller diameter and crown length. In addition, the need to reach the canopy delayed the process of branching the canopy of the unbound trees, reducing biomass requirements per unit of height growth.

Trees of the same height with shorter crowns are one of the objectives of forest management, since they represent a higher proportion of stem without branches, which, in practice, means lower costs with silvicultural treatments. The results obtained in this study demonstrate that the release of young trees from C. canjerana should not be performed as a management technique for this purpose, since emergent trees that remained under competition presented higher height of the branches insertion. Costa and Finger (2017) also found an inverse relationship between competition and canopy length, and that trees under competition showed higher height of the canopy insertion point, resulting in a higher proportion of clean wood, with no need for debris.

Although many authors comment on the strong relationship between diameter increment and competition, the similarity in the growth rate in diameter of liberated and non-liberated trees demonstrates that other factors are influencing the growth of trees in the area and they are responding in a similar way to the variations. Environmental factors may influence growth alone or together, but there are some that are closely linked to the diametric growth of trees, such as precipitation (SCHNEIDER and SCHNEIDER, 2008).

The decreasing incremental rate of the dominated released trees demonstrates that the self-competition is affecting the development of the plants of this group. One solution to this problem would be to perform slabs in the groups formed by the species even after release. Selective cuts would decrease intraspecific competition, by eliminating severely dominated plants, and promote the growth of potential trees with the aim of increasing the number of emergent trees and, consequently, increased wood volume of the species.

The rate of increase in height was also similar for LE and NLE trees as well as LD and NLD. The fall in height growth of emerging trees under competition in the last year may be linked to the fact that these trees have already managed to reach the canopy and possibly from now on will invest more in growth in diameter.

Another hypothesis for the reduction of height growth is the exhaustion of the productive capacity of the forest site, explained by the local soils. According to Carvalho (2002), canjerana develops better on fertile, deep soils with good drainage. However, the Neosols are soils with low depth, characterized by hindering root growth in addition to being of low fertility (EMBRAPA, 2013).

\section{CONCLUSIONS}

- The release provided a greater increase in diameter and height in liberated trees.

- The release can be carried out in young plants of the species with different dimensions when the interest is to promote growth in diameter, but the released plants only respond to the increment in height when they have height less than $100 \mathrm{~cm}$.

- Trees of the species that emerged presented greater increment in diameter and height than trees that remained dominated, regardless of whether or not they were released.

- Liberated trees presented greater crown length in relation to trees of the same non-liberated sociological group.

FLORESTA, Curitiba, PR, v. 49, n. 3, p. 553 - 560, jul/set 2019. 
- The maintenance of the trees under natural competition provided greater height of insertion of the branches in the shaft, which in practice means a larger proportion of tree trunks.

\section{REFERENCES}

ALMEIDA, DS Some principles of natural succession applied to the recovery process. In: Environmental recovery of the Atlantic Forest [online] .3rd ed. rev. and enl. Ilhéus/BA. Editus, 2016, pp. 48-75. ISBN 978-85-7455-440-2. Available from Scielo Books.

ALVARES, CA; STAPE, JL; SENTELHAS, PC; GONÇALVES, JLM; SPAROVEK, G. Köppen's climate classification map for Brazil. Meteorologische Zeitschrift, v. 22, n. 6, p. 711-728, 2013.

CARVALHO, PER Canjarana. Technical Circular, n ${ }^{\circ}$ 67. Embrapa Florestas, Colombo, PR, 2002.

COSTA, E. A.; FINGER, C. A. G. Efeito da Competição nas Relações Dimensionais de Araucária. Floresta e Ambiente, n. 24, 11p. 2017.

DAWKINS, H. C. The refining of mixed forest, a new objective for tropical silviculture. Empire Forestry Review, v. 2, n. 34, p. 188-191, 1995.

EMPRESA BRASILEIRA DE PESQUISA AGROPECUÁRIA - EMBRAPA. Centro Nacional de Pesquisa de Solos. Sistema brasileiro de classificação de solos, 3 ed. Rio de Janeiro, 2013. 353 p.

ESQUIVEL, M. J.; HARVEY, C. A.; FINEGAN, B.; CASANOVES, F.; SKARPE, C. Effects of pasture management on the natural regeneration of neotropical trees. Journal of Applied Ecology, v. 45, p. 371-380, 2008.

HUGHES, RF; UOWOLO, AL; TOGIA, TP Recovery of native forest after removal of an invasive tree, Falcataria moluccana, in American Samoa. Biological Invasions, v. 14, n. 7, p. 1393-1413, 2012.

LINKEVICIUS, E.; KULIESIS, A.; RÖHLE, H.; SCHRÖDER, J.; ALEINIKOVAS, M. The impact of competition for growing space on diameter, basal area and height growth in pine trees. Baltic Forestry, v. 2, n. 20, p. 301-313, 2014.

ORTEGA-PIECK, A.; LÓPEZ-BARRERA, F.; RAMÍREZ-MARCIAL, N.; GARCÍA-FRANCO, J. G. Early seedling establishment of two tropical montane cloud forest tree species: the role of native and exotic grasses. Forest Ecology Management, v. 261, p. 1336-1343, 2011.

PEÑA-ClAROS, M.; PETERS, E. M.; JUSTINIANO, M. J.; BLATE, G. M.; FREDERICKSEN, T. S.; PUTZ, F. E. Regeneration of commercial tree species following silvicultural treatments in a moist tropical forest. Forest Ecology and Management, v. 255, p. 1283-1293, 2008.

PRETZSCH, H. Forest dynamics, growth and yield from measurement to model. Heidelberg, Springer, Berlin, 2009. p. 664.

PRODAN, M.; PETERS, R.; COX, F.; REAL, P. Mensura Forestal. San José: Deustsche Gesellschaf für Technische Zusammenarbeit; 1997. $561 \mathrm{p}$.

SCARPINATI, E. A. et al. Influência do modelo de análise estatística e da forma das parcelas experimentais na seleção de clones de Eucalyptus spp. Revista Árvore, Viçosa, v. 33, n. 4, p. 769-776, 2009.

SCHNEIDER, P. R.; SCHNEIDER, P. S. P. Introdução ao manejo florestal. 2. ed. Santa Maria, RS: UFSM, FACOS, 2008. $566 \mathrm{p}$.

SMITH, DM The Practice of Silviculture. Eighth ed. John Wiley, New York, 1986. 527 p.

SOUZA, DV; CARVALHO, JOP; MENDES, FS; MELO, LO; SILVA, JNM; GARDIM, FCS Growth of tree species in a natural terra firme forest after harvesting of wood and silvicultural treatments, in the municipality of Paragominas, Pará, Brazil. Ciência Florestal, Santa Maria, v. 25, n. 4, p. 873-883, 2015.

STAGE, A. R. Prediction of Height Increment for Models of Forest Growth. USDA Forest Service Research Paper, INT-164, Ogden, Utah, 1975. $32 \mathrm{p}$.

STERBA, H. Waldwachstumskunde: Skriptum zur Lehrveranstaltung. Wien: Universität für Bodenkultur, Institut für Waldwachstumsforschung, 2006, $129 \mathrm{p}$.

TAFFAREL, M.; GOMES, J. M.; CARVALHO, J. O. P.; MELO, L. O.; FERREIRA, J. E. R. Efeito da silvicultura póscolheita na população de Chrysophyllum lucentifolium Cronquist (Goiabão) em uma floresta de terra firme na amazônia brasileira. Revista Árvore, Viçosa, v. 38, n. 6, p. 1045-1054, 2014.

VATRAZ, S.; CARVALHO, J. O. P.; GOMES, J. M.; TAFFAREL, M.; FERREIRA, J. E; R. Efeitos de tratamentos silviculturais sobre o crescimento de Laetia procera (Poepp.) Eichler em Paragominas, PA, Brasil. Scientia Forestalis, v. 40, n. 93, p. 95-102, 2012.

VILLEGAS, Z.; PEÑA-CLAROS, M.; MOSTACEDO, B.; ALARCÓN, A.; LICONA, J. C.; LEAÑO, C.; PARIONA, W.; CHOQUE, U. Silvicultural treatments enhance growth rates of future crop trees in a tropical dry forest. Forest Ecology and Management, v. 258, p. 971-977, 2009.

ZANINE, A. DE M.; SANTOS, E. M. Competição entre espécies de plantas - uma revisão. Revista da FZVA. Uruguaiana, v. 11, n. 1, p. 10-30. 2004 